DOI https://doi.org/10.32782/2305-9389/2020.22.08

УДК 94(100)»1920\1930»

Кузнець Тетяна,

доктор історичних наук, професор, завідувач кафедри історії України

Уманського державного педагогічного університету імені Павла Тичини

\title{
ПОВСЯКДЕННЕ ЖИТТЯ РАДЯНСЬКИХ МІСТ 1920-1930-Х РОКІВ
}

У статті на основі вивчення широкого кола наукових праџь і об'єктивно представленої у них структури дослідження, наявного емпіричного матеріалу автором актуалізовано питання вивчення повсякденного життя міського населення на історичному відрізку часу другої половини 1920-х - першої половини 1930-х років. У цей період у країні відбувалося формування нової політичної системи, вироблялися елементи нового повсякденного життя. Становлення нового типу суспільства, щзо відбувалося у той час, потягнуло за собою докорінні зміни у його соиіальній структурі, матеріальному середовищі існування і духовній сфері соиіального буття.

Дослідження повсякденного життя радянського міста у цеей період історії представляє значний науковий інтерес для розуміння і комплексного осмислення глибоких трансформаџій епохи, які закладали основи радянського ладу на довгі десятки років. Важливість дослідження повсякдення радянських міст иього періоду дає змогу найповніше розкрити складний илях формування особливого специфічного типу особистості - «радянської людини». Ці роки являють собою важливий перехідний період, шео суттєво вплинув на всі боки життя держави і суспільства. Характерною рисою «перехідності» стала поява мільйонів мешканців радянських міст, як столиць, обласних иеентів, так і периферійних містечок, яким довелося змінити звичний спосіб життя: стати учасниками масштабних внутрішніх міграцій, сочіально-економічних зрушень, відчути на собі усі негаразди побутових проблем, щзо знайшло своє відображення у структурі повсякдення та в менталітеті містян. Соціальні зрушення, якість життя населення мали визначальний вплив на історичний прочес, формуючи саму нову людину, ї̈ спосіб життя, відповідну їй культуру. У повсякденні другої половини 1920-х - першої половини 1930-х років формувалися витоки багатьох проблем сучасного життя пострадянського суспільства.

Ключові слова: форсована індустріалізація, радянські міста, повсякдення, житлові проблеми, система розподілу, торгівля.

\section{Kuznets Tetiana. Everyday life of Soviet cities in the 1920s - 1930s}

The study of many scientific works, the structure of the research objectively presented in them and the available empirical material have enabled the author of the article to actualize the issue of everyday life of the urban population between the second half of the 1920s and the first half of the 1930s. At that time, the country was creating a new political system and developing elements of a new everyday life. In turn, the establishment of a new type of society had entailed radical changes in its social structure, material environment and the spiritual sphere of social life.

The research on the everyday life of Soviet cities in this historical period is of considerable scientific interest for a comprehensive understanding of the profound transformations of the era, which had laid the foundations of the Soviet system for many decades. The importance of studying the then everyday life of Soviet cities allows one to fully reveal the complex creation of a special personality, that is "a Soviet person". These years represent an important transition which had significantly affected all aspects of the life of the state and society. Such "transition" also lies in the emergence of millions of residents of Soviet cities, including capitals, regional centres and peripheral towns, who needed to change their usual way of life, namely, to participate in large-scale internal migration and socio-economic changes and experience all the housing problems. Moreover, it found its reflection in the structure of the everyday life and mentality of citizens. Such aspects as social changes and the quality of life of the population significantly influenced the historical process, creating a very new person, his or her way of life and the corresponding culture. The origins of many of today's problems in the post-Soviet society indeed date back to the second half of the 1920s and the first half of the 1930s.

Key words: forced industrialization, Soviet cities, everyday life, housing problems, distribution system, trade.

В історії держави під назвою Союз Радянських Соціалістичних Республік період другої половини 1920-х - першої половини 1930-х років являє собою радянський варіант модерності. Це був важливий перехідний етап, що змінив, без перебільшення, усі боки життя суспільства і самої держави. Він став унікальним за своєю суттю часом, де уживалися старе і нове, періодом соціально-політичних трансформацій та економічних експериментів. Саме тоді на довгі десятиліття закладалися основи майбутньої радянської моделі розвитку. Процеси модернізації у сфері політики, ідеології, економіки, освіти та культури мали значний вплив на повсякденний рівень життя пересічних людей, соціальних груп, трудових колективів, конкретних родин. Із цього погляду дослідження повсякдення має включати «форми поведінки і стратегії виживання, якими користуються люди у специфічних соціально-політичних умовах, у тому числі й найбільш екстремальних» [1, с. 38]. Сучасні дослідники під повсякденням 
розуміють «...сферу людської буденності у множинних історико-культурних, політичних, етнічних і конфесійних контекстах» [2, с. 94].

Означений хронологічний період став часом соціальних експериментів і пошуку нових форм організації побуту містян. Рубіжними подіями, що вплинули на повсякденне життя міст і, відповідно, визначили верхню хронологічну межу дослідження серединою 1930-х років, стали рішення радянського уряду щодо питань поліпшення житлового будівництва та припинення безсистемної забудови міст, про скасування всесоюзної карткової системи розподілу основних продуктів харчування та непродовольчих товарів, зміна державної політики у сфері шлюбно-сімейних відносин.

Такий науковий напрям, як історія повсякдення, уже давно не байдужий сучасним дослідникам. Не $є$ винятком і тема повсякденного життя радянських міст. Саме місто, як і простір міського соціальноекономічного та культурного розвитку, у радянській історіографії завжди були обділені увагою. Лише в останні роки 3'явилися праці дослідників, що присвячені проблемам повсякдення радянських міст міжвоєнного періоду. В історіографії досліджуваної проблеми виділимо чотири тематичних блоки: дослідження, присвячені соціальній історії СРСР та історії радянського повсякдення 1920-1930-х років [3-6]; регіональні дослідження різних аспектів життя населення міст [7-9]; праці зарубіжних дослідників, що стосуються усіх цих аспектів [10-12]; дослідження сучасних істориків [13-15].

Метою статті $є$ вивчення історичного процесу формування і розвитку міського повсякдення в умовах індустріалізації. Дослідження радянського повсякдення 1920-1930-х років дає змогу розкрити складний шлях формування багатьох типових рис радянського способу життя, серед яких можна побачити стереотипи масової свідомості, ставлення до праці і власності, норми соціальної моралі та культури. Варто вивчати середовище, у якому доводилося жити і працювати радянській людині, «...прагнути до висвітлення процесу олюднення побуту, психологізації щоденного життя та ставлення людини до повсякденних проблем» [16, с. 289]. На побут городян впливають житло, його соціальна та архітектурно-просторова ієрархія, домашнє начиння, техніка тощо. Впливають на стиль життя також розвиток міського комунального господарства та транспорт, доступність та асортимент товарів широкого вжитку. Саме цей зв'язок між середовищем і побутом містян і $є$ найбільш адекватним шляхом до моделювання побутової історії міського населення 1920-1930-х років [17, с. 12].

На XIV з’ізді ВКП(б), що відбувся у грудні 1925 р., вище партійно-державне керівництво СРСР взяло курс на індустріалізацію. Це був перший етап модернізації країни Рад, який разом із колективізацією та культурною революцією мав вивести ії з економічної відсталості і забезпечити стабільний економічний та соціальний розвиток. В основу політики індустріалізації закладалася стратегія прискореного розвитку імпортозаміщеної промисловості.

Завдання індустріалізації набули більшої конкретизації після XV партійної конференції, що проходила в Москві з 26 жовтня по 3 листопада 1928 р. Резолюцією пленуму ЦК ВКП(б), що відбувся 18-24 листопада 1928 р., передбачалося посилення темпів індустріалізації СРСР. Міста ставали центрами промислового розвитку. Створення там підприємств вимагало значних капіталовкладень та людських ресурсів. Головним джерелом постачання ресурсів для індустріалізації стало село.

Важливим чинником усіх економічних, політичних і соціальних процесів у державі виступає людський ресурс. Значний вплив на демографічні процеси 1920-1930-х років мали розгорнута владою форсована індустріалізація, колективізація та політика розкуркулення. Саме вони спричинили різке перетікання сільського населення до міст, сприяли бурхливому їх розвитку. 31928 по 1932 р. міське населення СРСР зросло на 44\%. Фактично за п'ять років число міських жителів збільшилося на стільки ж, як і за попередні 30 років [18, с. 329]. За період соціалістичної індустріалізації багато міст перетворилися на обласні центри з відносно розвиненою як для того часу інфраструктурою. Зростав освітній і культурний рівень населення.

У цей час найактуальнішим аспектом повсякденного життя міст постало житлове питання. Незважаючи на значний приріст міського населення, нові будинки практично не будувалися, міста були перенаселені. Переважна більшість будівель у містах після революції стала власністю держави. Розпорядником цього житлового фонду була міська влада, яка визначала розміри житлової площі на одну особу. Загалом по СРСР іï розміри коливалися від 5,5 м² (наприклад, у Москві) і до 3,4 м² на одного мешканця (у регіонах). [12, с. 88]. Компенсувати відсутність стратегії та можливостей житлобудування взялися насадженням політики «ущільнення» або «підселення», суть якої полягала у конфіскації житла «ворогів» радянської влади або перетворення багатокімнатної квартири колись однієї сім’ї на комуналку $[19$, с. 143]. Життя в комуналках поряд з іншими, зовсім чужими людьми, різними за походженням, рівнем освіти перетворювалося на пекло та призводило до конфліктів у цій «малій комуні», часом із кримінальними наслідками. 
У містах із розвиненою промисловістю житло і комунальні послуги надавалися за рахунок підприємств, тому в той період характерною і невід'ємною рисою життя в СРСР стало будівництво для робітників житла «полегшеного типу». Так утворювалися «відомчі містечка» 3 гуртожитків, бараків або навіть землянок. Одноповерхові бараки формували пейзажі міських околиць і слугували переважно житлом для неодружених робітників. У гуртожитках же селили студентів, а також молодих кваліфікованих робітників і службовців. Іноземці, які жили у 1930-х роках у Магнітогорську, описували життя у бараках так: «...невисоке дерев’яне, побілене приміщення, подвійні стіни закладені соломою. Дах, покритий руберойдом, навесні завжди протікав. Вузький і довгий коридор освітлювала одна лампочка... У маленьких кімнатах було по два ліжка, стіл, табуретка і цегляна пічка. Маленьке вікно заклеювали газетами, щоб не дуло... У бараках не було ванної і водопроводу... У найбільш великих бараках, розрахованих на сто осіб, часто проживало по двісті і більше, на ліжках спали, як і працювали на підприємствах, позмінно» [12, с. 124].

По-іншому розв'язувалося питання забезпечення житлом партійної номенклатури, керівників великих підприємств, установ та організацій. Тут також існувала своя ієрархія. Наприклад, квартири сім'ям державних діячів видавалися з розрахунку одна кімната на члена сім’ї плюс кабінет, їдальня чи вітальня. Окрім квартир у містах, членам партійної номенклатури та їхнім сім'ям надавалися також державні дачі. Квартири і дачі вважалися власністю держави й утримувалися з бюджету. Залежно від рангу і заслуг номенклатура отримувала заміські будинки на курортах Криму і на Кавказі. Знаходилися вони у зручних місцях із закритою територією, зі своїми спецмагазинами, спецїдальнями, кінотеатрами, бібліотеками, спортивними майданчиками [20, с. 198].

Упродовж усього досліджуваного нами періоду первинним мотивом влади було не лише забезпечення громадян житлом (хоча і ця мета, безумовно, малася на увазі), а й забезпечення тотального контролю з боку державних структур над розподілом і використанням житлової площі. За подібного одержавлення житлового фонду під загрозою виселення за будь-яку провину опинявся кожний, що перетворювало житло на потужний інструмент державного примусу, тоді як поліпшення житлових умов у часи тотального дефіциту житла ставало досить вагомим матеріальним заохоченням і способом зарахування до привілейованих верств суспільства. До того ж концентрація людей у комунальних квартирах робила приватне життя більш прозорим і контрольованим. Це, а також існуючі ідеологічні уявлення про «новий вид побуту», що грунтувався на колективізмі, стало однією 3 причин того, що житлове питання так і не мало свого вирішення у 1930-х роках, оскільки держава не була зацікавлена в масовому наданні своїм громадянам індивідуальних квартир.

Процеси урбанізації створили масу й інших проблем, з якими новій владі не було ні часу, ні ресурсів боротися. Усе частішими ставали махінації з житлом. Щоб його отримати, люди йшли на укладання фіктивних шлюбів, розлучень, прописували чужих людей як родичів, здавали в оренду «ліжка», «кутки», кімнати за досить високими цінами. Гостро постала проблема забезпечення містян медичним обслуговуванням, продуктами харчування, одягом. Зростання міст потребувало розвитку інфраструктури, системи соціального забезпечення. Велика скупченість людей, антисанітарія призводили до спалахів хвороб, зростання рівня смертності, скорочення народжуваності і низької тривалості життя.

Характерною гендерною особливістю населення цього періоду історії була чисельна перевага жінок над чоловіками. Коріння цих проблем сягали років Першої світової війни, революцій та післяреволюційної нестабільності, коли втрати років військового протистояння порушили співвідношення статей. Зрівняння у правах із чоловіками дало можливість жінкам активно включатися у суспільні та виробничі процеси. Жінки були задіяні практично в усіх професіях. Зайнятість жінок на виробництві та громадській роботі змінювала сімейні відносини. Часто жінки, які віддавалися роботі і досягали там значних результатів, мали проблеми в родині. Рукоприкладство та домашнє насилля були одними з головних сімейних проблем цього періоду. Влада намагалася боротися із цими негативними явищами, надавала їм огласку. Широко практикувалися судові розгляди, з виховною метою проводилися показові суди. Влада і громадськість намагалися притягувати до відповідальності чоловіків, які неналежно ставилися до своїх дружин і дітей, зобов’язували їх сплачувати аліменти та турбуватися про своїх рідних.

У містах тривалий час зберігалося співіснування двох протилежних тенденцій. 3 одного боку, містяни притримувалися традиційних поглядів на виховання дітей і становища жінки, з іншого - ставали активними прихильниками нових шлюбно-сімейних відносин. У цілому в містах спостерігалася дестабілізація сім’і, що відповідало загальнорадянським тенденціям. Значно послабився інститут шлюбу за рахунок правової повноцінності незареєстрованного співжиття та спрощеної процедури розлучень $[21$, c. 24$]$. 
Бурхливий розвиток промисловості сформував соціальну структуру радянських міст. У 1930-ті роки процеси індустріалізації та соціально-стратифікаційної модернізації суспільства породжували складність соціальної адаптації містян до нового способу життя. Характерним для цього періоду стало зростання питомої ваги робітників та їх міграція. Матеріальне становище населення міст повністю залежало від рівня заробітної плати, яка була досить низькою. Негаразди міського життя, складність адаптації до його викликів породжували девіантну поведінку, зростання злочинності та інших соціальних відхилень (алкоголізму, проституції, жебракування тощо). У складних соціально-економічних умовах мешканці міст поступово виробляли для себе стратегії виживання: дрібні крадіжки, шахрайство, заняття городництвом, махінації з продуктовими картками або ж ударна праця і надія на додаткову винагороду за неї.

У кінці 1920-х років відмова радянською владою від політики непу різко загострила в країні продовольчу проблему. У 1932-1933 pp. усі основні хліборобні регіони СРСР уразив голод, який забрав, за різними підрахунками, до 10 млн життів і на кілька років мав негативний вплив на народжуваність. Для більшості мешканців міст усе життя цього періоду перетворювалося на боротьбу за виживання пошук продуктів харчування, одягу та даху над головою. Наприклад, у 1933 р. у середньостатистичній робітничій сім’ї міста Москви, не кажучи вже про віддалені регіони, у раціоні були практично відсутні жири, бракувало молока і фруктів, а частка м'яса і риби становила п'яту частину від норми початку XX ст. [22, с. 77].

В умовах гострого дефіциту ресурсів держава мала розставити пріоритети у питаннях забезпечення населення продуктами харчування. Взяття курсу на прискорену індустріалізацію, а також проголошення СРСР державою диктатури пролетаріату останній був визнаний привілейованою верствою суспільства. Для забезпечення йому «привілеїв» у країні запроваджувалася карткова система розподілу продуктів харчування та товарів першої необхідності. Картковий розподіл став результатом продовольчої кризи, зумовленої колективізацією, наслідком політики прискореної індустріалізації та одним із засобів ії здійснення. Виправданням для запровадження карткової системи була необхідність пріоритетного і стабільного забезпечення міст і населення, задіяного у промисловому виробництві.

Українські міста Одеса, Маріуполь, Херсон, Київ, Дніпропетровськ були першими, де вже у 1928 р. апробувалася радянська карткова система розподілу хліба серед населення. На початку 1929 р. карткову систему запровадили в усіх містах СРСР. Започаткований із хліба, нормований розподіл поширювався й на інші дефіцитні продукти (цукор, м'ясо, масло, чай тощо), а до середини 1931 р. і на промислові товари. Робітники відносилися до першої категорії й отримували по 800 грамів хліба на день, члени їх родини - по 400 грамів. Службовці та члени їхніх родин належали до другої категорії та отримували по 300 грамів хліба. Третю категорію формували безробітні, інваліди, пенсіонери. Для них була визначена норма 200 грамів. Так звані нетрудові елементи (торгівці, служителі релігійних культів і домогосподарки, яким не виповнилося 56 років) карток узагалі не отримували [23].

У 1931 р. з'явилися перші постанови про продовольче забезпечення вчителів та лікарів. У містах ці категорії людей повинні були отримувати норми робітників промисловості того списку, до якого відносилося це місто. Однак, маючи монополію на постачання, держава не могла забезпечувати навіть робітників. Уряд не мав змоги дотримуватися встановленого асортименту та пайкових норм. Чого не скажеш про забезпечення продуктами харчування працівників партійно-державного апарату, яких прирівняли до робітників першої категорії. Для них створили мережу спеціальних закритих розподільників. Місячні норми до кінця 1931 р. були встановлені у такому розмірі: 2 кг м'яса, 3 кг ковбаси, 5 кг риби, 0,5 кг китової ікри, 5 банок консервів, по 1 кг жирів і сиру, 30 л молока, 10 штук яєць, по 1,5 кг цукру і сухофруктів [24, с. 137].

Така політика держави породжувала перманентний дефіцит, який став невід'ємним складником радянської економіки. Терміни «черга», «дістати» і «мати блат» не зникали зі словникового запасу радянської людини впродовж усього періоду існування СРСР. У 1929 р. вперше у містах почали спостерігатися перебої з постачанням магазинів хлібом, з'явилися черги, в яких люди проводили десятки годин. Однак дефіцит не обмежився тільки хлібом. На полицях магазинів перестали з'являтися й інші життєво необхідні продукти харчування та споживчі товари. Таке становище відображало як пріоритети державного виробництва, зорієнтованого на розвиток важкої промисловості, так і наслідки знищення ремесел, дрібного приватного товаровиробника. Та навіть і ті товари, що потрапляли на полиці крамниць, були низької якості. Така політика держави спонукала до крадіжок як за місцем роботи, так і в побуті.

Ситуація дещо змінилася, коли у 1930-1936 рр. у містах СРСР були відкриті магазини системи «Торгзін» [25]. На своїх полицях вони мали широкий асортимент дефіцитних товарів, які реалізували за іноземну валюту, золото, срібло та інші цінності. Двері цих магазинів були відкриті для всіх, хто 
володів цими засобами. Створюючи мережу закладів торгівлі системи «Торгзін», держава переслідувала мету мати стабільне джерело наповнення бюджету, сформувати запаси твердої валюти, забезпечити імпорт машин та устаткування для потреб індустріалізації.

Загалом у першій половині 1930-х років у СРСР розпочали кампанію зі створення державної системи роздрібної торгівлі. ІІї метою було подолати кризу розподілу, що розгорілася після ліквідації приватних i кооперативних магазинів у 1929-1930рp. Реформа означала серйозне корегування більшовицького політичного курсу. У період кризи постачання довелося відмовитися від попередніх цінностей революційного аскетизму і від уявлення про поступовий перехід у майбутньому до системи прямого обміну. До середини 1930-х років виробництво товарів народного споживання почало зростати, у містах створювалася нова мережа магазинів, а у масовій свідомості почав формуватися новий позитивний образ радянської торгівлі, тісно пов'язаний з індустріалізацією, «культурністю», прагненням «наздогнати i перегнати» Захід. Реформа роздрібної торгівлі була намаганням наслідувати європейську культуру масового споживання. Особливо яскраво це простежувалося на прикладі організації роботи міських магазинів. Виникла нова ідентичність - радянський споживач. Здійснювалося активне залучення жінок до роботи у сфері торгівлі, що призвело до своєрідної «фемінізації» й окреслило суттєві зміни в гендерних відносинах.

Отже, здатність вжитися в епоху, подивитися на події очима людей конкретного історичного часу може допомогти історія повсякденності. Повсякденне життя радянських міст 1920-х - першої половини 1930-х років складно структуроване, багатогранне і суперечливе. Зміни, що відбувалися в ході реалізації політики форсованої індустріалізації, мали свій вплив на чисельність та соціальну структуру населення міст СРСР. Форсований розвиток важкої промисловості на тлі явного незабезпечення соціальної сфери міст призводив не лише до маргіналізації населення, а й виникнення диспропорції між чисельністю населення міста і розвитком інфраструктури.

Підсумовуючи, варто зазначити, що 1920-1930-ті роки стали періодом небачених до того зрушень у способі життя містян, до якого країни Заходу йшли десятками років. Реальність буття формувала новий уклад життя мешканців міст. Вони опинилися вирваними зі звичних умов існування. Трансформації, і не завжди в кращий бік, торкнулися усього: побуту, культури, особистих відносин. Задуманий радянською владою «культурний стрибок» став падінням у прірву, кардинально змінив побут містян, поставив їх на межу виживання. Часто повсякдення містян було близьким до похідних умов, що змушувало їх закривати очі на дискомфорт і проявляти винахідливість. Життя в перенаселених бараках чи комунальних квартирах позбавляло містян відчуття приватного куточка, де можна було б сховатися від депресії суцільної розрухи. Забезпечення населення житлом, нормоване постачання продуктами харчування та товарами першої необхідності стали елементами каральної системи радянської держави та призвели до штучного обмеження самих потреб міського населення. Такі умови міського життя, обмеження матеріально-побутових можливостей громадян породжували соціальні аномалії та девіантну поведінку, а зміни в шлюбно-сімейних відносинах провокували сімейне насилля.

\section{Література:}

1. Бергер П., Лукман Т. Социальное конструирование реальности. Трактат по социологии знания. Москва : Медиум, 1995. $393 \mathrm{c}$.

2. Пушкарева Н.Л. «История повседневности» и «история частной жизни»: содержание и соотношение понятий. Соииальная история : ежегодник. Москва, 2004. С. 93-113.

3. Милютин Н.А. Проблема строительства социалистических городов: основные вопросы рациональной планировки и строительства населенных мест СССР. Москва, 1930. 82 с.

4. Болотин 3.С. Вопросы снабжения. Москва : Соцэкгиз, 1934. 140 с.

5. Березовский С. Трудящиеся женщины - в социалистическое строительство. Москва, 1931. 87 с.

6. Ким М.П. Коммунистическая партия - организатор культурной революции в СССР. Москва, 1955. 164 с.

7. Букин С.С., Исаев В.И. Новосибирцы. Очерки истории повседневной жизни. Конец XIX - начало XXI вв. Новосибирск : Сибирское научное издательство, 2008. 270 с.

8. Поляков Ю.А. Человек в повседневности (исторические аспекты). Вопросы истории. 2000. № 3. С. 125-132.

9. Токменинова Л. Екатеринбург - Свердловск: Архитектурная лихорадка 20-30-х годов. Наука Урала. 1992. № 10. C. 12-23.

10. Kotkin S. Magnetic mountain. Stalinism as a civilization. Berkley. 1993. 158 p.

11. Скотт Дж. За Уралом. Американский рабочий в русском городе стали. Москва ; Свердловск, 1991. 305 с.

12. Фицпатрик Ш. Повседневный сталинизм. Социальная история Советской России в 1930-е гг.: город. Москва : РОССПЭН, 2008. $450 \mathrm{c}$.

13. Лебина Н.Б. Повседневная жизнь советского города: Нормы и аномалии. 1920-1930-е годы. Санкт-Петербург : Летний Сад, 1999. 320 c. 
14. Меерович М.Г. Наказание жилищем. Жилищная политика в СССР как средство управления людьми. 1917-1937 гг. Москва : РОССПЭН ; Фонд «Президетский центр Б.Н. Ельцина», 2008. 303 с.

15. Повседневный мир советского человека 1920-1940-х гг. : сборник научных статей / под ред Е.Ф. Кринко, Т.П. Хлыниной. Ростов-на-Дону, 2009. 384 с.

16. Удод О.А. Історія повсякденності: питання історіографії, методології та джерелознавства. Проблеми історії України $X I X$ - початку XX столітmя : збірник наукових праць, присвячений пам'яті академіка НАН України Ю.Ю. Кондуфора. 2004. № 2. С. 286-313.

17. Борисенко М. Побут міських мешканців України в 30-х роках ХХ століття. Етнічна історія народів Свропи. 2008. Вип. 24. С. 12-18.

18. О народнохозяйственном плане на 1931 год : Постановление ЦК ВКП(б), 1930 г. КПСС в резолюииях и решениях съездов, конферениий и пленумов ЦК, 1925-1953. Москва : Госполитиздат, 1953. Ч. 2. 1204 с.

19. Бригадина О.В. «Жить стало лучше, жить стало веселей»: жилищно-бытовые условия жизни городского населения СССР в 1930-е гг. Пращы гістарычнага факультэта БДУ : навук. зб. Вып. 9 / рэдкал.: У.К. Коршук (адк. рэд.) [і інш.]. Минск : БДУ, 2014. С. 142-156.

20. Богословская М.В. Повседневная жизнь советской элиты в 1920-1930 гг. Конфликты и компромиссы в истории мировых ичивилизаций : сборник статей. Москва : РГГУ, 2009. 215 с.

21. Макарова М.Н. Повседневная жизнь Магнитогорска в 1929-1935 гг. : автореф. дис. ... канд. ист. наук : 07.00.02. Челябинск, 2010. 31 с.

22. Осокина Е.А. Иерархия потребления. О жизни людей в условиях сталинского снабжения. 1928-1935 гг. Москва : МГУ, 1993. $400 \mathrm{c.}$

23. Енциклопедія сучасної України. Т. 12: «Кал-Киї» / гол. редкол. І.М. Дзюба та ін. ; Ін-т енциклопедичних досліджень НАН України. Київ, 2012. URL: http://esu.com.ua/search_articles.php?id=10176.

24. Осокина Е.А. За фасадом «сталинского изобилия». Распределение и рынок в снабжении населения в годы индустриализации. 1927-1941. Москва : РОССПЭН, 2008. 380 с.

25. Осокина Е.А. Золото для индустриализации: «Торгсин». Москва : РОССПЭН, 2009. 592 с. 